\title{
JuST RELATIONSHIPS: DESISTANCE FOR REENTRY COURTS
}

\author{
ERIC J. MILLER*
}

\section{INTRODUCTION}

Social roles play an important part in the criminal process. At the front end, where individuals are targeted, arrested, adjudicated, and sentenced, criminal law re-enforces attitudes towards responsibility and fault by apportioning moralistic roles of offender and victim. At the back end, when individuals are released from jail or prison, the re-entering person perhaps hopes to be similarly transformed from offender, to ex-offender, to simply (productive) member of society. ${ }^{1}$ This power to transform is, however, dependent upon different resources ${ }^{2}$ and people, including officials in the criminal justice system, the public, and the person charged with a crime.

Problem-solving courts regard themselves as transformative institutions, ${ }^{3}$ able to induce persistent offenders to change their ways by addressing the causes of their offending. ${ }^{4}$ The courts themselves claim to adopt a novel role in the criminal

* Professor and Leo J. O'Brien Fellow, Loyola Marymount University Loyola Law School. My thanks to Professor Lahny Silva for encouraging me to engage with desistance theory, and her thoughtful comments on this project.

1. See, e.g., Victoria Malkin, The End of Welfare as We Know It: What Happens When the Judge Is in Charge, 25 CRITIQUE ANTHROPOLOGY 361, 368 (2005) ("[P]roblem-solving courts . . . aim[ ] . . . to transform defendants into productive citizens if they take this 'opportunity to change' and accept responsibility for themselves."); Kerwin KAYE, ENFORCING FreEDOM: DrUG Courts, Therapeutic Communities, And the Intimacies of the State 34 (2020) (“[D]rug court practitioners sometimes refer to their aims in these regards as the creation of NORPs: normal, ordinary, responsible persons."); Shadd MARUnA, MAKIng Good: How Ex-CONVICTS Reform and Rebuild Their Lives 87-88 (2001) [hereinafter Maruna, Making Good] (describing ways people who exit criminal conduct change their personal narrative).

2. Those resources are usually identified as employment, marriage, military service, and so on. See, e.g., John H. Laub \& Robert J. Sampson, Turning Points in the Life Course: Why Change Matters to the Study of Crime, 31 Criminology 301, 304 (1993) [hereinafter Laub \& Sampson, Turning Points].

3. See, e.g., Anthony C. Thompson, Releasing Prisoners, Redeeming Communities: ReEntry, Race, And Politics 154 (2008) [hereinafter Thompson, Releasing Prisoners]; Philip Bean, Drug Courts, the Judge, and the Rehabilitative Ideal, in DRUG COURTS IN THEORY AND IN PrACTiCE 235-36 (James L. Nolan, Jr. ed., 2002) ("The drug courts claim to be reinventing justice is manifested inter alia in the fundamental transformation of courtroom procedures."); JANE Donoghue, Transforming Criminal Justice? Problem-Solving and Court Specialisation (2014).

4. See, e.g., Jonathan Lippman, Foreword to Greg Berman \& John Feinblatt, Good Courts: The Case for Problem-Solving Justice (Quid Pro Books 2015) (2005) [hereinafter Berman \& Feinblatt, Good Courts] (“ Defendants were also provided with on-site services, including mental health counseling, GED classes, and job training. These services gave participants the opportunity to transform their lives, support their families, and strengthen their communities."); 
justice system, ${ }^{5}$ one that transforms the posture of the judge from a remote and impartial umpire to an engaged and supportive ally; and the other court agents from formalist adversaries to a collegial team. The process itself morphs from one dominated by a legalistic narrative of due process to a more casual and curative outlook. And all of this is directed towards transforming the problem-solving court's participants from addicts ${ }^{6}$ and offenders to graduates and normal, ordinary, responsible people. ${ }^{7}$

The power to transform is normative, political, and psychological. Such power is normative and political because social standards and legal rules operate to assign roles to individuals, however they might wish to be regarded. Both the formal legal process and informal social expectations constitute our responses to individuals charged with crimes. The power to transform is psychological because some available social roles require the individual to be willing and able to assume the relevant mantle. Some people find it easy to conform to legal and social expectations; others cannot or choose not to. For those people who struggle to cope with the transformation from prison to society, reentry courts purport to facilitate the conversion from offender and recidivist to normal person and productive contributor to society.

Desistance is a psychological, criminological theory. It recognizes that the way people view themselves as stuck in social roles can impede or motivate the transformation from active criminal to productive citizen. ${ }^{8}$ When offenders repeatedly commit crimes, desistance claims that is often because the person regards themselves locked in the criminal role. ${ }^{9}$ Although many people will naturally switch out of that role, desistance theory claims some success in hastening the transformation process by leveraging the power of social

Rebecca Tiger, Judging Addicts: Drug Courts and Coercion in the Justice System 7 (2013) (“ [D]rug courts are viewed by their advocates as a 'revolutionary' approach, . . . offering [defendants] the way to transform their lives according to prevailing medicalized and behavioral theories of addiction and recovery.”); Erin R. Collins, Status Courts, 105 GEO. L.J. 1481, 1482-83 (2017).

5. See, e.g., Greg Berman \& John Feinblatt, Problem-Solving Justice: A Quiet Revolution, 86 JudiCATURE 182, 182 (2003); John Feinblatt et al., Institutionalizing Innovation: The New York Drug Court Story, 28 FordhaM URB. L.J. 277, 278 (2000).

6. James L. Nolan, JR., Reinventing Justice: The American Drug Court Movement 142 (2001) [hereinafter NolAn, JR., REINVENTING JustiCE] ("Judge Schma . . . agrees that in the drug court the admittance of guilt is 'pretty much immaterial.' More important to him is that defendants 'admit that they are addicts. That's what I want them to do.'”); JENNIFER MurPHY, Illness or Deviance? Drug Courts, Drug Treatment, And the Ambiguity of Addiction 169-71(2015).

7. Nolan, JR., Reinventing Justice, supra note 6, at 64 .

8. Beth Weaver, Understanding Desistance: A Critical Review of Theories of Desistance, 25 Psychol., CRIME \& L. 641, 646 (2019).

9. Shadd Maruna, Desistance from Crime and Explanatory Style: A New Direction in the Psychology of Reform, 20 J. CONTEMP. CRIM. JUST. 184, 196-98 (2004) [hereinafter Maruna, Desistance from Crime]; see MARUNA, MAKING GoOD, supra note 1. 
relationships to motivate personal change. ${ }^{10}$ Authoritative facilitators act as change agents, enabling desistors to recognize themselves as having the power to affect how their lives go: to become an agent, rather than a patient, selecting a new role giving new meaning to their lives. Reentry courts propose a similar, transformative relationship between judge and participants, with the judge as a motivational, therapeutic cheerleader.

However, empowering social relationships - and their ability to motivate action - are not distributed equally across society. ${ }^{11}$ The distribution of this —as with any-form of social power is a matter of social justice. Unequal access to empowering roles and relationships entails unequal opportunity for personal change. Unfair demands may require people to adopt social roles that fail to make sense of their social situation or require them to participate in their own oppression.

Particularly in a society that entrenches subordination along lines of race, gender, class, disability, sexual orientation, housedness, and national origin, just to name a few, social roles that conform to the dominant class's understanding of propriety may undermine the ability of a person in a subordinated group to adopt a self-respecting role. ${ }^{12}$ Resistance to dominant notions of law and order, and to the officials and symbols of authority within that dominant legal and social structure, may be proper, ${ }^{13}$ if impurely so, ${ }^{14}$ ways of resisting injustice.

Some of these forms implicate the state directly and indirectly. The state exercises power directly through the relationships it creates with offenders. The state exercises power indirectly to the extent it makes relationships among families, employers, friends, and civic institutions more or less available and more or less impactful. Civil society too is responsible for the social context in

10. See, e.g., Fergus McNeill et al., Reexamining Evidence-Based Practice in Community Corrections: Beyond "A Confined View" of What Works, 14 Jus. REs. \& POL'Y 35, 40-42 (2012) [hereinafter, McNeill et al., Reexamining Evidence-Based Practice]; see also Michael Massoglia \& Christopher Uggen, Subjective Desistance and the Transition to Adulthood, 23 J. ConTEMP. CRIM. Just. 90, 95-96 (2007); Laub \& Sampson, Turning Points, supra note 2, at 311; John H. Laub \& Robert J. Sampson, Understanding Desistance from Crime, 28 CRIME \& JUST. 1, 5-6 (2001) [hereinafter Laub \& Sampson, Understanding Desistance].

11. Two types of social relationship in particular form the basis for desistance theories: those relationships that produce "bridging" and "bonding" social capital. See, e.g., Beth Weaver \& Fergus McNeill, Traveling Hopefully: Desistance Theory and Probation Practice, in What ElsE WORKs?: CReAtive Work With OfFenders 36, 41 (Jo Brayford et al. eds., 2010). As Weaver and McNeill note, some groups, such as women, Black people, and Muslim people, may have less access to bridging and bonding social capital than other groups due to systemic discrimination. $I d$. at 54 .

12. See Tommie Shelby, Dark Ghettos:Injustice, Dissent, And Reform 95-100 (2016).

13. See, e.g., Robin D. G. Kelley, Race Rebels: Culture, Politics, and the Black Working Class 205 (1994).

14. See SHelby, supra note 12, at 259-60. For Shelby, impure means impermissible, because it violates a legal or social norm, but not blameworthy, because the protest contests the validity of either the norm itself or the state's right to govern (to have authority) over the group given other failures to govern. 
which people reentering society from prison and jail must try to create, restore, and maintain the sorts of relationships that enable them to access productive social roles. Within reentry courts, the criminal process must not simply transform the roles of judge, attorney, and probation official, but it must do so in ways that acknowledge the profoundly political power that grounds all of these relationships.

Currently, reentry courts - and problem-solving courts in general - transform the roles and powers of government officials without necessarily effecting a similar transformation of the roles of the people whom the court is supposed to serve. The problem-solving court presents itself as a radical institution in the criminal process, based upon its distinctive procedure and effects on participants, ${ }^{15}$ but ends up being profoundly conservative in its understanding of people under the supervision of the criminal process, while at the same time significantly empowering the judges that oversee that process. ${ }^{16}$

The argument in this Article proceeds in four sections. In Section I, I describe the structure of problem-solving courts in general, and reentry courts in particular, by considering the manner in which the courts engage in a form of transformative role assignment. Like all problem-solving courts, reentry courts do not directly address the problem of reentry, nor even the problem of reoffending, but rather the problem of recycling ${ }^{17}$ : how the judicial system proposes to cope with individuals who return to court repeatedly. Problem-solving courts address the problem of recycling by constituting judges, conceptualized as leaders of the therapeutic approach to criminal rehabilitation, as powerful change-agents. These judges set out to transform the role of the participants, first from criminal to client; then from client to cured by targeting some underlying, crime-causing disability. Assigning the reentering person a thick role within the court structure allows the court personnel to assign themselves a thick role, too.

In Section II, I suggest that, because problem-solving courts address the problem of persistent recycling through powerful change agents, they look like desistance courts. Theories of desistance, like the problem-solving court movement, treat probation as a transformative process organized around change agents and designed to prevent the problem of recycling people through the institutions of criminal punishment. Desistance is an exemplary cycle-exiting process. It describes not only the process itself, but also the end-state of exiting the cycling process by changing roles from criminal to socially productive person

15. Peggy Fulton Hora \& Theodore Stalcup, Drug Treatment Courts in the Twenty-First Century: The Evolution of the Revolution in Problem-Solving Courts, 42 GA. L. REV. 717, 725-27 (2008).

16. See, e.g., KAYE, supra note 1, at 59-61; TIgER, supra note 4, at 97; JENNIFER MURPHY, supra note 6, at 67-69; Erin R. Collins, The Problem of Problem-Solving Courts, 54 U.C. DAVIS L. REV. 1573, 1594-95 (2021).

17. See, e.g., Nora V. Demleitner, Stopping a Vicious Cycle: Release, Restrictions, ReOffending, 12 FED. SENT'G REP. 243, 246-47 (2000); Cyrus Tata, Beyond the Revolving Court Door: Is It Time for Problem-Solving Courts in Scotland?, 1 SCOT. Just. MATTERS 17, 18 (2013). 
as well as social recognition of new role. ${ }^{18}$

In Section III, I shall represent desistance theory as a political theory of material and psychological power. Desistance theories have been interested in particular aspects of social relations: individual capabilities and motivations to persist in or resist criminal activity; the social context that empowers individuals to engage in or refrain from criminal acts; social and legal institutions or organizations that enable or inhibit criminal activity; and the capacity of police, probation officials, prosecutors, defense counsel, judges, and other officials to persuade people to exit the criminal process. That power is not equally distributed across persons or society and so implicates important questions of political power and social justice. ${ }^{19}$

In Section IV, I argue that reentry courts are indeed transformative institutions, just not in the manner imagined by desistance theory. ${ }^{20}$ The primary target of problem-solving courts is the role of the judge. It is the social and legal standing of the judge and their self-conception that receives a boost in the problem-solving court. For the most part, the medicalized model practiced in reentry courts simply reconfigures the disciplinary process of low-level criminal courts into a language of cognitive behavior-modification that applies familiar labels of wrongdoing, culpability, and responsibility onto individuals struggling to overcome mental, physical, and social disabilities.

\section{REPOSITIONING ROLES}

In the age of mass incarceration, mass prisoner reentry presents a vast ongoing problem for the criminal justice system. Inevitably, people in prison and jail are released back into society. Each year, approximately 600,000 people reenter their communities from jail or prison, ${ }^{21}$ with people in federal detention accounting for about 70,000 of those released. ${ }^{22}$ Yet a significant portion of those individuals are caught in a cyclical pattern, not just of reentry into civic society, but also of re-exit out of it and back into incarceration. ${ }^{23}$

18. Weaver, supra note 8 , at 642 .

19. Fergus McNeill, What Works and What's Just?, 1 Eur. J. Prob. 21, 35-36 (2009) [hereinafter McNeill, What's Just?]; Fergus McNeill, A Desistance Paradigm for Offender Management, 6 CRIMINOlogy \& CRIM. Just. 39, 49-52 (2006) [hereinafter McNeill, Desistance Paradigm].

20. See, e.g., Shadd Maruna \& Thomas P. LeBel, Welcome Home? Examining the "Reentry Court" Concept from a Strengths-based Perspective, 4 W. CRIMINOLOGY REV. 91, 97-99 (2003).

21. Joan Petersilia, What Works in Prisoner Reentry? Reviewing and Questioning the Evidence, 68 Fed. Prob., no. 2, Sept. 2004, at *7 [hereinafter Petersilia, What Works]. The overwhelming majority of people reentering society do so from state prisons and jails; nonetheless, the federal population is still significant. See Joan Petersilia, Prisoner Reentry: Public Safety and Reintegration Challenges, 81 PRISON J. 360, 360 (2001).

22. Caitlin J. Taylor, Balancing Act: The Adaptation of Traditional Judicial Roles in Reentry Court, 51 J. OfFEnder ReHabilitation 351, 351 (2012).

23. The overwhelming majority of people reentering from the federal system are subject to 
In 2001, the federal government launched the Reentry Court Initiative, creating nine pilot reentry court sites. ${ }^{24}$ The enactment of the Second Chance Act in 2007 provided funding and an increased impetus for the creation of federal reentry courts. ${ }^{25}$ According to the Federal Judicial Center, there were 100 federal problem-solving courts as of 2018, of which seventy-three were reentry courts. ${ }^{26}$

Reentry courts are part of the larger, problem-solving court movement, and are designed to address this churn of repeat, long-term, mostly low-level offenders through the criminal docket by mitigating the underlying disabilities that drive recidivism. ${ }^{27}$ Their goal is to channel offenders out of the cycle of reexit and reentry by addressing the underlying causes of repeated offending. ${ }^{28}$ Problem-solving courts address long-term, ingrained, repeated criminal conduct, claiming to move offenders away from these behaviors by transforming the way they think about themselves and their conduct. ${ }^{29}$

Problem-solving courts remain extremely popular: the federal embrace of reentry courts saw exponential growth between 2001 and 2018, with the 2007 federal Second Chance Act coinciding with a spur in court growth (see Figure 1, below). ${ }^{30}$

a period of supervised release lasting, on average, just under four years. Almost half will be rearrested within eight years of release. See Timothy D. DeGiusti, Innovative Justice: Federal Reentry Drug Courts-How Should We Measure Success, 82 Fed. Prob., no. 3, Dec. 2018, at 11, 11-12.

24. Claire McCaskill, Next Steps in Breaking the Cycle of Reoffending: A Call for Reentry Courts, 20 FED. SENT'G REP. 308, 308 (2008).

25. Id. at 309.

26. Email from Mark Sherman, Assistant Div. Dir., Probation \& Pretrial Servs. Educ., Fed. Judicial Ctr., (Apr. 11, 2018) (on file with author) (listing all the "federal problem solving courts that we are aware of').

27. Christine S. Scott-Hayward, Rethinking Federal Diversion: The Rise of Specialized Criminal Courts, 22 Berkeley J. Crim. L. 47, 85-88 (2017).

28. Demleitner, supra note 17 , at 244-45.

29. See id.

30. See, e.g., Email from Mark Sherman, supra note 26. 


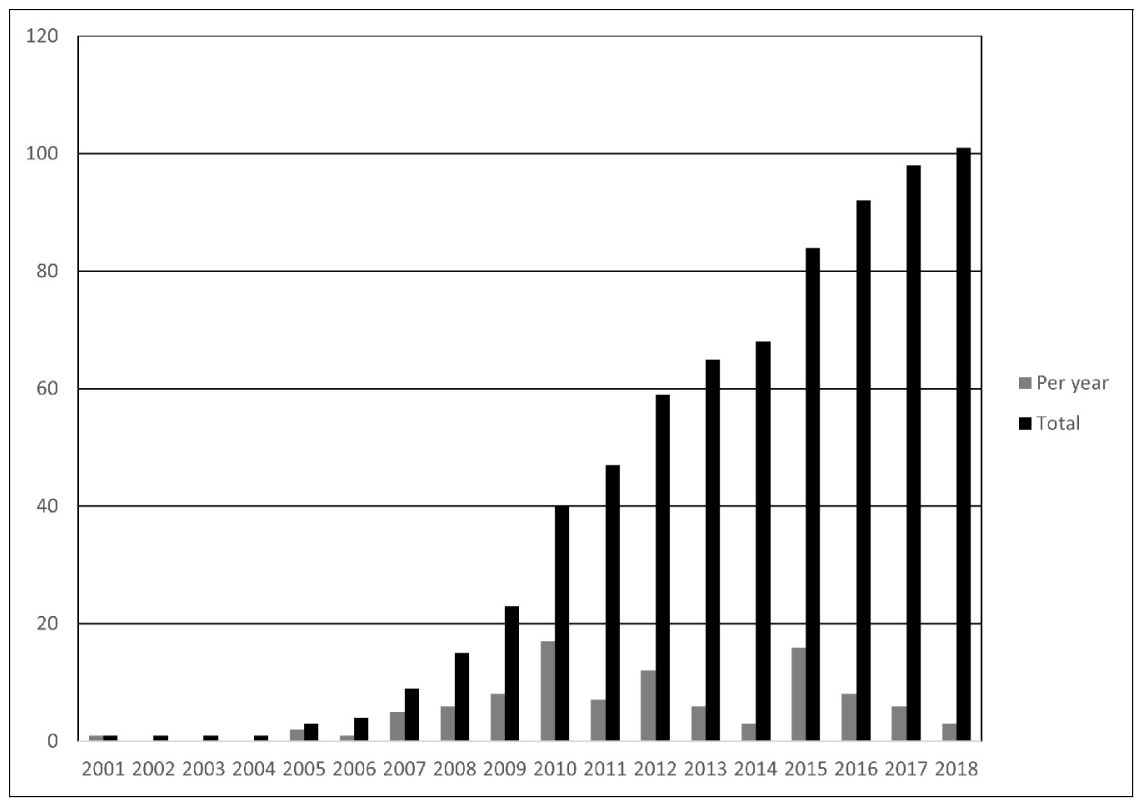

Figure 1 - Growth of Federal Problem-Solving Courts 2001-2018. ${ }^{31}$

Though popular with judges - in particular, federal magistrate judges - the data supporting the effectiveness of problem-solving courts, and in particular federal reentry courts, is quite mixed. ${ }^{32}$ A core feature has been the spotty quality of data collection that precludes effective comparison among courts. ${ }^{33}$ Another feature has been a radical shift in reviewers' understanding of what sorts of drug court candidate best fit the court's methods. ${ }^{34}$ More recently, however, the federal court

31. Id.

32. See, e.g., Richard C. Boldt, Problem-Solving Courts, in Reforming CRIMINAL JustiCe 284-88 (Erik Luna ed., 2017) [hereinafter Boldt, Problem-Solving Courts]; Collins, The Problem of Problem-Solving Courts, supra note 16, at 1587 ("Thus, while the courts are retrospectively datajustified, they are not 'data-driven' in the sense that they are not actually built upon data proving they effectively fulfill their mission. Instead, they seem to be fueled-especially in the early years - by anecdotal accounts of success provided by the inaugural judges.").

33. See, e.g., Boldt, Problem-Solving Courts, supra note 32, at 284-85.

34. Compare Peggy Fulton Hora et al., Therapeutic Jurisprudence and the Drug Treatment Court Movement: Revolutionizing the Criminal Justice System's Response to Drug Abuse and Crime in America, 74 Notre Dame L. Rev. 439, 482 (1999) [hereinafter Fulton Hora et al., Therapeutic Jurisprudence] (low-level, non-violent drug possessors or drug purchasers admitted to drug court), with West Huddleston \& Douglas B. Marlowe, Painting the Current Picture: A National Report on Drug Courts and Other Problem-Solving Courts in the United States, NAT'L DRUG CT. INST. at 17 (July 2011), https://www.ndci.org/sites/default/files/nadcp/PCP\%20Report\% 
system has reviewed its reentry court program. For the most part, while there is some evidence that certain courts are an effective means of avoiding cycling through the criminal process, the evidence is at best mixed, and at worst shows that problem-solving courts have little impact on the various measures of success. ${ }^{35}$

\section{A. How Reentry Courts Work}

Problem-solving courts, of which federal reentry courts are a subset, are specialist courts. ${ }^{36}$ They require distinctive expertise on the part of the judge or the court staff, docket distinctive categories of case, and they engage with a few of the distinctive social and psychological vulnerabilities that drive individuals towards committing crimes. ${ }^{37}$

Attorney General Janet Reno described the governing philosophy of reentry courts - and indeed problem-solving courts in general — in the following terms:

$\mathrm{Th}[\mathrm{e}]$ reentry court is modeled on the . . . theory of a carrot and stick approach . . . in using the strength of the court and the wisdom of the court to really push the issue . . . The reentry court would promote positive behavior by the returning offender. It would marshal resources to support the offender's successful reintegration into society. The court would also use its powers of punishment, using the graduated range of swift, predictable sanctions, to make sure that the individual stays on the right track. Judges working closely with others would approach or could approach a plan for reintegrating the offender into the community. The court would then monitor and enforce the plan. The partners of court would include institutional and community correctional officers, law enforcement, local businesses, family, clergy, support services, victim advocates and neighborhood organizations. ${ }^{38}$

Five central elements are key to the reentry model: (1) the court addresses persistent offending by people who have long-term contacts with the criminal process; (2) the court targets classes of people characterized primarily by special vulnerabilities or disabilities; (3) the court engages with the problem of persistent offending by requiring participants to remediate the identified vulnerabilities and disabilities through a predetermined program of support, incentives, and

20FINAL.PDF [https://perma.cc/F7RM-H4D3] ("Research identifies that the 'High Risk/High Need' population of offenders respond optimally to the Drug Court model and yield the greatest returns on investment. These individuals are (1) compulsively addicted to drugs and/or alcohol and (2) have failed other treatment or supervisory interventions.").

35. See, e.g., Scott-Hayward, supra note 27, at 85-88.

36. Ursula Castellano, Problem Solving Courts: Theory and Practice, 5 Soc. Compass 957, 957 (2011); Scott-Hayward, supra note 27, at 109.

37. Donoghue, supra note 3, at 37 (2014).

38. Stephen E. Vance, Federal Reentry Court Programs: A Summary of Recent Evaluations, 75 Fed. Prob., no. 2, Sept. 2011, at*109. 
sanctions; (4) the court continuously evaluates compliance with the program through a non-custodial, court-centered process of regular judicial monitoring; and (5) an inter-disciplinary, teamwork-driven structure facilitates the remediation and monitoring process. ${ }^{39}$

First, the courts address persistent offending. ${ }^{40}$ For example, when she was Dade County District Attorney, Janet Reno supported the creation of the Miami Drug Court to address traditional courts' inability to nip reoffending in the bud. ${ }^{41}$ Instead, "first time offenders[] were simply getting credit for time served. They were not getting treatment, they were not getting punished, and they were coming back in six weeks, or in a year." 42 Attorney General Reno's justification for problem-solving court reflects a core concern of reentry court: a cycling-throughthe-docket worry. The problem is that the person passing through the criminal justice system becomes a repeat offender who does not get channeled down and out of the system or up and into prison but simply churns round and round the system in a cycle of re-entry and re-exit.

Second, the court tracks people with various forms of precariousness or disability. Problem-solving courts generally identify people with one specific problem: addiction to drugs, mental illness, homelessness, and so on. ${ }^{43}$ These are people who are often viewed as particularly disturbing or disordering to everyday life. ${ }^{44}$ Problem-solving courts take a primarily medicalized, rehabilitative approach, focused on eradicating the underlying social, physical, or psychological impairments that produced the participant's contacts with the criminal process. ${ }^{45}$

39. See generally Tata, supra note 17 , at 17.

40. See Christine H. Lindquist et al., Reentry Courts, in EnCyclopedia of CRiminology AND CRiminal Justice 4351-60 (Gerben Bruinsma \& David Weisburd eds., 2014).

41. See James J. Chriss, The Drug Court Movement: An Analysis of Tacit Assumptions, in Drug Courts in Theory and in Practice 189, 193 (James L. Nolan, Jr. ed., 2002).

42. Id. at 193. The courts have since moved on from addressing primarily people convicted of a crime for the first-time to engaging with more people who are serious or more persistent offenders.

43. Vance, supra note 38, at 65.

44. See, e.g., Stacy Lee Burns, The Future of Problem-Solving Courts: Inside the Courts and Beyond, 10 U. MD. L.J. RACE, RELIGION, GENDER \& ClASS 73, 80-85 (2010) (discussing various forms of problem-solving court). One way to think of a problem-solving court is as a location for socially marginal, disordering bodies subject to various forms of social exclusion because they may make "normal" people uncomfortable: Disability scholar Lennard Davis identifies these disordering groups as including "homeless people, impoverished people, end-stage cancer patients, the comatose, heroin, crack, or methamphetamine addicts." LENNARD J. DAVIS, THE END OF NormaL: IDENTITY IN A BIOCULTURAL ERA 4 (2013). Many of these groups are targeted for criminal processing and monitoring by problem-solving courts. $I d$.

45. On the medical model, especially in the context of disability studies, see, e.g., Arlene S. Kanter, The Law: What's Disability Studies Got to Do with It or An Introduction to Disability Legal Studies, 42 Colum. Hum. RTs. L. Rev. 403, 407 (2011); Rabia Belt \& Doron Dorfman, Disability, Law, and the Humanities: The Rise in Disability Legal Studies, in THE OXFORD HANDBOOK OF LAW \& Humanities 143-61 (Simon Stern et al. eds., 2019); Craig Konnoth, Medicalization and the New 
Third, the court requires the people it supervises to take personal responsibility for their rehabilitation. ${ }^{46}$ A core feature of the model requires the participants to sign a contract that charts the steps they are responsible for taking through both the treatment and socialization process. ${ }^{47}$ In reentry courts, this may take the form of a "reentry transition plan." 48 The court does create its own treatment team, but many of the addiction services are those already provided by the city, county, or state; and the court certainly does not create novel welfare programs. ${ }^{49}$ Instead, the courts assess personal responsibility by determining how well participants comply with a relatively onerous system of drug testing, attendance at addiction programs, engagement with community service programs, and so on. ${ }^{50}$

Fourth, the court engages in prolonged, intensive, continuous monitoring of the selected people. Reentry programs usually last around twelve months, with meetings in the courtroom with the judge and the program support team between once and twice a month. ${ }^{51}$ Problem-solving court judges evaluate, sanction, and reward compliance with the conditions of pre- or post-trial, or - in the case of reentry courts - post-incarceration release orders. ${ }^{52}$ Failure to comply with the rehabilitation program results in a series of graduated sanctions that eventually result in short periods of prison time, or removal from the program. ${ }^{53}$

Perhaps most importantly, reentry courts - like all problem-solving courts - locate a large part of the monitoring process inside the courtroom. The courtroom practice is characterized by a dynamic, active relationship between the judge and the person on supervised release. ${ }^{54}$ The judge attempts to use that relationship to alter the reentering person's cognitive processes and behavioral practices so that they will abstain from the underlying disorderly activities that

Civil Rights, 72 Stan. L. REv. 1165, 1165-66 (2020).

46. See, e.g., Eric J. Miller, Drugs, Courts, and the New Penology, 20 Stan. L. \& Pol'y Rev. 417, 440-42 (2009) (discussing the emphasis on responsibility for recovery as a responsibilization strategy).

47. Id. at 433 .

48. Thompson, Releasing Prisoners, supra note 3, at 155.

49. See, e.g., Richard C. Boldt, Rehabilitative Punishment and the Drug Treatment Court Movement, 76 WASH. U. L.Q. 1205, 1227-28 (1998) [hereinafter Boldt, Rehabilitative Punishment].

50. DeGiusti, supra note 23, at 13.

51. See Michael J. Newman \& Matthew C. Moschella, The Benefits and Operations of Federal Reentry Courts, 64 FED. LAW., Dec. 2017, at 27-35 (discussing various federal reentry programs).

52. Eric J. Miller, Drugs, Courts, and the New Penology, supra note 46, at 448.

53. See DeGiusti, supra note 23, at 11-20; Vance, supra note 38, at*64-73. Different forms of problem-solving court may use jail time less frequently or not at all. While a feature of the problem-solving methodology is supposed to be the use of graduated sanctions, the type and intensity of sanction applied is, to a large extent, up to the individual courts.

54. Eric J. Miller, The Therapeutic Effects of Managerial Reentry Courts, 20 FED. SENT'G REP. 127, 128-29 (2007). 
brought them to court in the first place. ${ }^{55}$

Fifth, to help the judge through this process, the problem-solving court model calls for the formation of a team led by a judge and joined by the prosecutor and defense attorney, a probation officer, and usually a treatment provider. The judge and attorneys are asked to transcend their traditional roles and broaden their normal objectives in a criminal case. ${ }^{56}$ Specifically, judges and attorneys are tasked with working collaboratively to help justice-involved persons remain lawabiding. ${ }^{57}$

\section{B. Transforming Roles}

Reentry courts, like all problem-solving courts, expressly change the nature of the roles played by the participants. Three role-changes in particular garner a lot of attention: the reentering person, the judge, and defense counsel. Under the problem-solving model, the participant "becomes a client of the court, and judge, prosecutor, and defense counsel must shed their traditional roles and take on roles that will facilitate an offender's recovery from the disease of addiction." ${ }^{58}$

Problem-solving courts assign a series of roles or identities to the people who participate in the process. ${ }^{59}$ The courts use a more-or-less formalized narrative that participants can rely upon to negotiate the stages of moving through the process. ${ }^{60}$ These narratives may vary somewhat from court to court, but they gain structure through the core features of problem-solving courts and the contractualist model of progression through the court. ${ }^{61}$ For present purposes, the two most important series of roles are those that apply to the defendant - or, in reentry court, the person under supervised release - and the judge. ${ }^{62}$

1. Defendant.-Problem-solving courts assign the defendant multiple roles through the reentry process. These roles place the participants within a narrative that enables them to give meaning to the process and the other participants and officials within it.

Through its labeling process, the court communicates its decriminalization of the defendant's status for purposes of the problem-solving court. Problem-

55. Eric J. Miller, Drugs, Courts, and the New Penology, supra note 46, at 435.

56. Matthew G. Rowland, Assessing the Case for Formal Recognition and Expansion of Federal Problem-Solving Courts, 80 Fed. ProB., no. 3, Dec. 2016, at 3, 4.

57. Eric J. Miller, Embracing Addiction: Drug Courts and the False Promise of Judicial Interventionism, 65 Оніо Sт. L.J. 1479, 1492-93 (2004).

58. Fulton Hora et al., Therapeutic Jurisprudence, supra note 34, at 469.

59. See, e.g., Malkin, supra note 1, at 377-78, 381.

60. Eric J. Miller, Embracing Addiction, supra note 57, at 1566.

61. Brooke Bedrick \& Jerome H. Skolnick, From "Treatment" to "Justice" in Oakland, California, in The Early Drug Courts: Case Studies in Judicial Innovation 52-53 (W. Clinton Terry, III ed., 1999).

62. Some reentry courts do away with the presence of lawyers altogether, and are staffed by the judge, probation officials, and treatment service providers. See ThOMPson, Releasing PRISONERS, supra note 3, at 164-65. 
solving courts usually identify the participant as a "client," so emphasizing the court's service orientation; but also - in the drug court models of problem-solving court-as primarily an "addict," and so someone receiving treatment, not punishment. $^{63}$

The therapeutic role allows for relapse so long as the participant progresses through various formally identified stages of the process. Problem-solving courts regard relapse as part of the process to transform the participant from the role of addict to that of abstinent, from client to graduate, which in turn allows the court to complete the formal process of decriminalization by dismissing the participant's judgment. ${ }^{64}$

Problem-solving courts generally have a particular rhetoric through which participants express acceptance or endorsement of the courts' values. It is important ... that clients tell the right story . . . [and] follow[ ] a particular script. . . . That is, clients are expected to accept a particular worldview, a particular understanding of themselves, and they are expected to express this understanding according to therapeutically defined categories. Not telling the right story . . . is also interpreted in therapeutic terms. The person who fails to accept treatment-with a certain attitude, using the right words - will be interpreted as being in denial, as not complying, as not buying into treatment. Failure to tell the right story can have serious consequences for the client. ${ }^{65}$

The courts' rhetoric serves a variety of functions: an expressive function to demonstrate to the court officials that the participant is "getting with the program" $"$; a strategic function that offers the participant a set of terms with which to negotiate sanctions with the various officials ${ }^{67}$; a cognitive function, which emphasizes the participant's ability to make choices to relapse or progress $^{68}$; a responsibilization function, which places the onus of connecting with programming and resocialization upon the participant ${ }^{69}$; and a reflective function, which provides a language and a space in which the participant can reflect about other places within and without the criminal process and perhaps imagine a life independent of the criminal process. ${ }^{70}$ These functions may be available to various participants depending upon their ability to engage with the court in these different ways.

Some narratives are excluded even if true; for example, regarding oneself as a victim of social injustice. A politicized recognition of the disparate impact of

63. Eric J. Miller, Embracing Addiction, supra note 57, at 1493.

64. Id. at 1494-95.

65. Nolan, JR., ReinVEnTING Justice, supra note 6, at 123-24.

66. Id.

67. Malkin, supra note 1, at 368 .

68. Eric J. Miller, Embracing Addiction, supra note 57, at 1512.

69. See, e.g., TIGER, supra note 4, at 7 (discussing " the explicit 'responsibility' that is foisted on the defendants to be active participants in their own cure").

70. Id. 
the criminal process and the state's (and the court's) role in criminalization conflicts with the process of responsibilization and its rhetoric of choice. Victims of racial or economic injustice are marginalized by the demand that the participants take charge of their choices and contribute to their rehabilitation by personally building the resources and capabilities necessary to support their attempts at economic and social stability and abstinence. The exclusion of social justice narratives to adopt roles and give meaning to their experience within the criminal process may fall particularly hard on people of color. ${ }^{71}$

2. Judge.-The judge's role undergoes a double transformation. In problemsolving court, the judge (1) engages in a direct, more-or-less emotional and paternalistic relationship with the offender; and (2) is sovereign over the courtroom, the courthouse workgroup, and the criminal process.

The first relationship engages the judge as a novel change agent, working much like a probation officer to affect the participant's life outside the courtroom. Ordinarily, the judge possesses various unique or shared official legal resources empowering her to alter the participants' legal status as they move through the criminal process. ${ }^{72}$ The standard view of courtroom practice takes for granted that the judge will adopt a posture of detachment or neutrality, using rule-guided normative powers dispassionately. Emotion enters the courtroom only when legally relevant to reward or punish participants' expressions of remorse.

In the problem-solving court, the judge works directly on the participant's emotional and behavioral responses outside the structure of legal rules. ${ }^{73}$ The judge becomes not merely a legal, but also a moral and emotional, authority, whose role as "cheerleader, coach, mentor" " confers an expressive power to show anger, sadness, frustration, joy, happiness, satisfaction, and other emotions as a means of influencing the participants' beliefs and behavior.

In one of the most controversial aspects of the problem-solving court, ${ }^{75}$ the

71. Id.

72. This model of lower-level criminal court may be somewhat idealized. See MaLCOLM M. Feeley, The Process Is the Punishment: Handling Cases in a Lower Criminal Court 7-10 (1979) (discussing informal nature of lower criminal court workgroup).

73. See, e.g., Eric J. Miller, The Therapeutic Effects of Managerial Reentry Courts, supra note 54, at 128 (discussing the "collateral institutional authority" of the problem-solving-court judge). Ethnographies of lower-level criminal courts suggest that judges leverage their informal charismatic resources more often than the official model suggests, for good and ill. See, e.g., id.

74. Tiger, supra note 4, at 98.

75. See generally Tamar M. Meekins, Risky Business: Criminal Specialty Courts and the Ethical Obligations of the Zealous Criminal Defender, 12 BERKELEY J. CRIM. L. 75 (2007); Tamar M. Meekins, "Specialized Justice": The Over-Emergence of Specialty Courts and the Threat of a New Criminal Defense Paradigm, 40 Suffolk U. L. Rev. 1 (2006); Michael Pinard, Broadening the Holistic Mindset: Incorporating Collateral Consequences and Reentry into Criminal Defense Lawyering, 31 Fordham Urb. L.J. 1067 (2004); Mae C. Quinn, Whose Team Am I On Anyway? Musings of a Public Defender About Drug Treatment Court Practice, 26 N.Y.U. REV. L. \& Soc. Change 37 (2001); Mae C. Quinn, An RSVP to Professor Wexler's Warm Therapeutic Jurisprudence Invitation to the Criminal Defense Bar: Unable to Join You, Already (Somewhat 
defense counsel is expected to step back and allow the judge to form the primary relationship with the defendant. ${ }^{76}$ Ideally, the judge seeks to establish a direct, emotional connection with the offender through which to alter the participant's sense-of-self and conduct, moving them from addict to abstainer.

Indeed, the identification, assessment, and communication of emotions are central to the change process that distinguishes the drug court program. Inasmuch as the drug court is committed to treating drug offenders, engagement with the defendant's inner life is a central preoccupation. The judge is not simply concerned with whether or not a "defendant" committed some illegal behavior but is actively involved in the process of helping the "client" or "patient" recover, heal, and overcome an addictive lifestyle. . . . The application of emotivist storytelling in the drug court setting . . . result[s] in a restructuring of court procedures. ${ }^{77}$

The second transformation places the judge at the top of the courthouse hierarchy, displacing the prosecutor's current domination of the criminal process ${ }^{78}$ While the prosecutor dominates the courthouse in the plea-bargaining model, the problem-solving regime restores judicial domination of the courthouse workgroup. ${ }^{79}$ The judge is the leader of a treatment team, and the other team

Similarly) Engaged, 48 B.C. L. ReV. 539 (2007); Anthony C. Thompson, Courting Disorder: Some Thoughts on Community Courts, 10 WASH. U. J.L. \& POL'Y 63 (2002) [hereinafter Thompson, Courting Disorder]; William H. Simon, Solving Problems vs. Claiming Rights: The Pragmatist Challenge to Legal Liberalism, 46 WM. \& MARY L. REV. 127 (2004); William H. Simon, Criminal Defenders and Community Justice: The Drug Court Example, 40 AM. CRIM. L. REV. 1595 (2003); David B. Wexler, A Tripartite Framework for Incorporating Therapeutic Jurisprudence in Criminal Law Education, Research, And Practice, 7 Fla. COASt AL L. Rev. 95 (2005); Fulton Hora et al., Therapeutic Jurisprudence, supra note 34.

76. Donoghue, supra note 3, at 38 (“[D] efence's allegiance is no longer to their individual client in the protection of confidential information, the pursuit of their client's wishes, and the duty to avoid interests that may conflict with those wishes: the defence's role is transformed when they operate within a problem-solving paradigm.”).

77. Nolan, JR., Reinventing Justice, supra note 6, at 112.

78. On prosecutorial domination of the criminal process, see, e.g., William J. Stuntz, The Collapse of AMERICAN CRiminal Justice (2011). This transformation thus actually replaces the judge at the top of the courtroom hierarchy. The now-standard account of the prosecutor's role is that the rise of plea-bargaining throughout the 1970s and 1980s, combined with the introduction of determinate sentencing regimes and overcriminalization, replaced the adjudicative process of the trial with an administrative system run out of the prosecutor's office. See, e.g., William J. Stuntz, The Pathological Politics of Criminal Law, 100 Mich. L. ReV. 505, 565-69 (2001). With prosecutors able to determine the charge and sentence length, judges were shuffled to the margins of the criminal justice system. See Berman \& Feinblatt, Good Courts, supra note 4, at 19 ("moving crucial decision-making authority away from judges and jurors and placing it in the hands of prosecutors").

79. Problem-solving courts negate prosecutorial domination of the criminal process. Rather 
members serve to support the judge-as-primary-change-agent's interactions with the participant.

The judge's managerial role expands and intensifies to leverage various administrative and adjudicative functions. In a traditional low-level criminal courtroom, the judge is a bureaucrat, enforcing courthouse and criminal procedures to oversee a rote and remote administrative system of mass adjudication from arraignment to plea-allocution dominated by the prosecutor. Judicial engagement operates to keep the process moving, mediating conflicts among lawyers and other court staff, and overseeing a system of conveyor-belt or "mass-production" justice in which participants receive little individualized attention from the court. ${ }^{80}$

From a procedural perspective, the court doubles down on the marginalization of adjudication. Problem-solving courts center the probationary process of supervising conditions of release. ${ }^{81}$ To facilitate the rehabilitation process, problem-solving courts minimize the stages leading to a guilty plea, ${ }^{82}$ which becomes a peripheral aspect of the adjudication process. ${ }^{83}$ The formerly marginal managerial processes of docketing cases and setting and monitoring conditions of release become central.

The court uses its power to schedule status hearings, set detailed conditions of release, issue bench warrants, hold contempt hearings, impose minor sentences for contempt, and suspend and dismiss final judgments or sentences to supervise and sanction participants. The judge can impose a complex and graduated set of release conditions at the outset of the problem-solving court period, then hold regular weekly (in the case of drug courts) or monthly or semi-monthly (in the case of reentry courts) hearings to determine compliance with those conditions and impose sanctions for failure to appear or contempt of court if the supervised person fails to turn up or violates their conditions. ${ }^{84}$

than a judiciary circumvented by the prosecutor, these courts corral the prosecutor as part of a teamoriented and judge-led institutional approach. Though the cost is the disappearance of the criminal trial, in this system of short, rapid pleas and lengthy probation supervision, the prosecutor's primary power becomes that of referring individuals to the court, and their role is to aid in monitoring the defendant's progress through the problem-solving process. TIGER, supra note 4, at 147.

80. See, e.g., Alexandra Natapoff, Misdemeanors, 85 S. CAL. L. REV. 1313, 1315 (2012) ("Massive, underfunded, informal, and careless, the misdemeanor system propels defendants through in bulk with scant attention to individualized cases and often without counsel." (citation omitted)).

81. See, e.g., Faye S. Taxman et al., Graduated Sanctions: Stepping into Accountable Systems and Offenders, 79 PRISON J. 182, 183 (1999).

82. Donoghue, supra note 3, at 39 ("Summary courts rely on the expeditious production of guilty pleas.").

83. TIGER, supra note 4, at 147 (critiquing drug courts as “"conviction mills,' requiring people to plead guilty to access them, often with little time to consider the consequences of this decision").

84. See Erin Murphy, Manufacturing Crime: Process, Pretext, and Criminal Justice, 97 Geo. L.J. 1435, 1447-48 (2009). 
In this process, the judge reconstitutes themselves as a therapeutic expert directly controlling the process of supervising offenders. The rhetoric of treatment and therapy replaces the language of due process, sentencing, and punishment. ${ }^{85}$ The goal of the process becomes cognitive treatment and behavior modification, and these terms are used to describe traditionally punitive practices of detention and rehabilitation. ${ }^{86}$ The various disciplinary locations expand the opportunities for social surveillance and control to include the probation office, the treatment center, the courtroom, various community service locations, the classroom, and the jail. ${ }^{87}$ The effect is to incapacitate the participant from prohibited conduct by overloading them with alternative requirements, where these are expressed in therapeutic language, such as "clinical" and "nonclinical" success. ${ }^{88}$

\section{PROBLEM-SOLVING COURTS AS DESISTANCE COURTS}

Problem-solving courts present themselves as pursuing the end state of abstinence from crime. The process is supposed to remove the impairments that produce crime through mandatory narcotics-anonymous meetings, counselling, drug-testing, community service, and education that culminates in the court-based status hearings. ${ }^{89}$ These judge-facilitated hearings are supposed to transform the identities of the participants in the eyes of both the participants themselves and the larger society. Given this structure, problem-solving courts have proved intriguing or attractive to desistance theorists, a collection of academics, and policymakers, who share this interest in offender role-transformation.

Desistance theories attempt to explain why people stop committing crimes. ${ }^{90}$ First arising in the context of ontogenetic or "life course" theories of criminal offending, desistance theories recognize that persistent criminals tend to have a fairly predictable career that begins around the teenage years, peaks fairly quickly, continues through their mid-twenties, and then rapidly declines. ${ }^{91}$ Desistance's goal is to lower the intensity and shorten the length of a person's

85. Problem-solving courts thus make explicit the rejection of due process that Malcolm Feeley identified as a feature of low-level criminal courts. See FEELEY, supra note 72, at 57-58.

86. See, e.g., Eric J. Miller, Embracing Addiction, supra note 57, at 1485-86.

87. See, e.g., Fergus McNeill, Pervasive Punishment: Making Sense of Mass Supervision 9 (2019) [hereinafter McNeill, Pervasive Punishment] (“ Most commonly, a person might be required to submit to regular probation supervision, to undertake unpaid work, to complete an 'offending behaviour programme', or to submit to certain forms of addiction-related, medical or psychiatric treatment. Curfews, exclusion orders and restrictions on travel can also be imposed, with or without electronic monitoring ('tagging').").

88. MurPhy, supra note 6, at 148 .

89. See Eric J. Miller, Embracing Addiction, supra note 57.

90. Weaver, supra note 8, at 641.

91. Shadd Maruna, Desistance and Development: The Psychosocial Process of 'Going Straight', 2 Brit. Criminology Conf.: Selected Proc. 1, 2 (1999). 
peak period of offending. ${ }^{92}$

Desistance theorists take a data-driven, evidence-based approach to understand "what works" to persuade people who are persistently engaged in criminal activity to abstain from re-offense. ${ }^{93}$ The various versions of desistance theory generally recognize that individuals "oscillat[e] between conformity and criminality" and seek to motivate people to break this cycle of offending by empowering them to make choices that promote conformity over criminality. ${ }^{94}$

There are three aspects to desistance: the desisting person's abstaining from crime, or what desistance theorists call "primary" or "act" desistance; the process by which to get them to abstain ("secondary" or "identity" desistance); and society's acknowledgment that the person is now abstaining from crime ("tertiary" or "relational" desistance). ${ }^{95}$ A core feature of secondary or identity desistance is the idea that people cease committing crimes when they embrace a new identity or social role. One influential identity-based desistance theory suggests that certain empowering narratives are effective in producing this shift in roles. ${ }^{96}$

Desistance also emphasizes the role of an authoritative facilitator to help the offender through a treatment process to re-integrate into society. "Desistance can, it seems, be provoked by someone believing in the offender; someone who perhaps carries hope and keeps it alive when the offender cannot do so for him or herself." ${ }^{\prime 7}$ For example, criminologist Shadd Maruna's strength-based model exemplifies the facilitator-led, role-transforming process, in which some figure, usually a social worker, builds a supportive relationship helping to motivate the participant to change their identity by changing the narrative of their life. ${ }^{98}$

The transformative process begins with the participant in the role of a passive, powerless patient, characterizing themselves as at the mercy of forces outside themselves which they cannot control. ${ }^{99}$ The facilitator works to help the participant shed the patient role and adopt a self-respecting, empowered, agent role, one that emphasizes the ways in which the person can positively contribute to society. ${ }^{100}$ These roles may build upon family relations, such as parent, husband, and so on, or upon other supportive personal relationships such as caregiver; emphasize economic self-sufficiency through various forms of employment; emphasize self-improvement through the role of student; and so on. ${ }^{101}$

92. McNeill, What's Just?, supra note 19, at 25-26.

93. Jessica M. Eaglin, Against Neorehabilitation, 66 SMU L. REV. 189, 189 (2013).

94. Weaver, supra note 8 , at 642 . Oscillation is another theme shared by the problem-solving court movement.

95. Id. at 642-43.

96. See generally Maruna, Desistance from Crime, supra note 9.

97. McNeill, What's Just?, supra note 19, at 27.

98. See generally Maruna, Desistance from Crime, supra note 9.

99. See id.

100. See id.

101. See, e.g., Laub \& Sampson, Understanding Desistance, supra note 10, at 49-54. 
Problem-solving courts share many of the features of the process of secondary or identity desistance, and share the end-goal of primary desistance or abstinence from both drug use and crime. The problem-solving court claims to possess two structural features valued by identity desistance: (1) a treatment program individualized to each participant's needs; and (2) supportive mentors - in particular, the problem-solving judge (but also the treatment team) - to develop the participant's motivation, provide education, and engage in advocacy to promote personal change. ${ }^{102}$

A prominent desistance theorist, Fergus McNeill, identified a variety of features that ought to be promoted by any desistance theory. ${ }^{103}$ These include empowering the participants to engage in the process of role-transformation; providing programs individualized to each participant's distinctive needs; expressly acknowledging structural, institutional, and interpersonal obstacles to the role-transforming process and the achievement of abstinence from crime (or other anti-social behaviors), including race, gender, poverty, and the criminal process itself; and recognizing that the mentor's role is to provide hope and empower the participant (not the mentor). ${ }^{104}$ On this view, "if desistance is about discovering agency, then interventions need to encourage and respect selfdetermination; this means working with offenders not on them." 105

What is notable, given the overlaps between problem-solving courts and narrative desistance theory, is the failure of desistance theory to make a dent in the world of problem-solving court practice. The failure to take up desistance theory is all the more remarkable given the evidence-based claims of both the problem-solving court movement and desistance theory, as well as the overlap between criminologists and probation experts writing about reentry courts and promoting desistance theory as a promising approach to probation and rehabilitation. ${ }^{106}$ I shall shortly suggest that the lack of purchase of desistance theory in problem-solving courts (where other theories, such as therapeutic jurisprudence and procedural justice, dominate) is revealing about the true functions of the court.

For example, in 2003, Maruna made a vocal push for problem-solving courts, and in particular, reentry courts, to reconceive themselves as desistance courts. ${ }^{107}$

102. Maruna \& LeBel, supra note 20, at 101-02.

103. McNeill et al., Reexamining Evidence-Based Practice, supra note 10, at 43-47.

104. See McNeill, What's Just?, supra note 19; see also McNeill, Desistance Paradigm, supra note 19; McNeill et al., Reexamining Evidence-Based Practice, supra note 10.

105. McNeill, What's Just?, supra note 19, at 28.

106. See, e.g., Petersilia, What Works, supra note 21, at 7 (endorsing drug courts); see generally Faye S. Taxman \& Jeffrey Bouffard, Treatment Inside the Drug Treatment Court: The Who, What, Where, and How of Treatment Services, 37 Substance Use \& Misuse 1665 (2002); Alese Wooditch et al., Which Criminogenic Need Changes Are Most Important in Promoting Desistance from Crime and Substance Use?, 41 CRIM. Just. \& BEHAV. 276 (2013).

107. See Maruna, MAKING Good, supra note 1, at 164 (endorsing reentry courts); Maruna \& LeBel, supra note 20, at 93 (2003) (same); JoAn Petersilia, When Prisoners Come Home: PAROle AND PRisoner REENTRy 209 (2003) (“Maruna strongly endorse[s] reentry courts.”). 
If only they would adopt the right narrative, he suggested, "instituted on a broad scale, the reentry court would represent a significant change in the structure of how the process of prison release works." 108 That new narrative would reject the "carrot" approach of prioritizing offender need, as well as the stick approach, which is oriented towards calculating and managing offender risk, "[b]oth [of which] are deficit models . . that . . . emphasize convicts" problems." Maruna argued, problem-solving courts should adopt a desistance narrative emphasizing offender "strengths" to ask "what positive contribution the person can make [to society]." 110

Moreover, the sorts of strengths that Maruna endorses superficially fit the responsibilization model adopted by problem-solving courts. ${ }^{11}$ Maruna argues that the desistance process provides participants with "a sense of hope, an orientation toward the future, and the willingness to take responsibility." 112 The end-state to which the participants aim is one in which the participants are able "to make amends, demonstrate their value and potential, and make positive contributions to their communities." 113 Here, Maruna suggests that the desistence process operates to provide a new social role in which the participant demonstrates that they are socially responsible, compliant, and deserving, thereby transforming not only their sense of identity, but society's sense of their identity as well (secondary and tertiary desistance). ${ }^{114}$

A narrative that values strengths, restoration, and redemption provides reentering individuals the opportunity to make a positive contribution to the community by performing some socially acceptable or valuable action. As I have discussed, problem-solving courts in general endorse a narrative of destigmatization and decriminalization, and seek to inculcate a rhetoric of treatment and personal transformation. Why, then, after Maruna's prodding in 2003, has there been so little cross-over from between problem-solving and desistance, apart from a few nods here and there in the desistance community to the reentry court as an important reentry model?

The answer is that desistance is, among other things, a theory of power. ${ }^{115}$ It seeks to leverage both personal and social power to transform the actual and perceived standing of particular members of the community: people with

108. Maruna \& LeBel, supra note 20, at 93.

109. Id. (emphasis added).

110. Id. at 97 .

111. On responsibilization, see Eric J. Miller, Drugs, Courts, and the New Penology, supra note 46 .

112. Maruna \& LeBel, supra note 20, at 97 (citation omitted); see also MARUNA, MAKING GooD, supra note 1, at 164.

113. Maruna \& LeBel, supra note 20, at 97.

114. Id.

115. See, e.g., Stephen C. McGuinn, Reentry, Desistance, and the Responsibility of THE STATE: LET THEM BACK IN 46 (2018) ("For too many men and women in prison, structural disadvantage has disempowered, manipulated, and owned them and their communities. Desistance needs to be about returning power, ownership, control.”). 
persistent contacts with the criminal process. For example, McNeill emphasizes the importance, not only of secondary desistance - the desistor's transformed understanding of themselves in relation to society-but also tertiary desistance - society's transformed understanding of the desistor. ${ }^{116}$ From the power perspective, desistance could be understood as a form of transformative justice. A feature of desistance as articulated by Fergus McNeill, among others, is the idea that not only must desistors learn to respect themselves, but that society must learn to respect desistors and find ways to integrate them into the familial, social, and economic bonds that can support their efforts to re-integrate into the community. ${ }^{117}$ Although working through individuals, desistance theory requires us to acknowledge and account for the ways in which the criminal process, along with the other institutions of governance and civic society, both helps and hampers people caught up in criminal offending. Holding the state accountable for failing to provide resources and criminalizing groups of offenders is precisely what the therapeutic talk of the problem-solving court places off the table.

\section{A POLITICAL THEORY OF DESISTANCE}

Desistance is a theory of citizenship. Citizenship describes the reciprocal relationships between state and citizen, and among citizens themselves, as equal members of the polity empowered to participate in self-governance. ${ }^{118}$ Reciprocity entails that the nature of these rights and responsibilities are conditional, and interlinked. The government's obligation is to treat its citizens as equals, establish responsive and inclusive structures of governance, and ensure a fair distribution of resources. ${ }^{119}$ In return, each citizen is responsible for supporting public institutions that promulgate shared, public, enforceable rules of conduct that enable us to act cooperatively and collectively. ${ }^{120}$

The ability to act cooperatively and collectively depends upon both personal

116. See, e.g., McNeill, Desistance Paradigm, supra note 19, at 53-54 (“[D]esistance research at least hints at the reciprocal need for society to make good to offenders"); see also McGuINN, supra note 115, at 42-44 (discussing the ways in which material and structural social disadvantage — what McNeill calls bonding and bridging social capital—can inhibit the personal transformation necessary for desistance).

117. See, e.g., McNeill, Desistance Paradigm, supra note 19, at 53-54; Weaver \& McNeill, supra note 11 , at 54 . Others who emphasize the need for society to reciprocally respond to desistance include Stephen McGuinn and Michaela Soyer. See, e.g., McGuINN, supra note 115, at 42-44; Michaela SOYER, ADREAm Denied:InCARCERATIOn, ReCidivism, AND Young MinORITY MEN IN AMERICA 5 (2016).

118. ShelBy, supra note 12, at 20; see also Ekow N. Yankah, The Right to Reintegration, 23 NEW CRIM. L. REV. 74 (2020).

119. Nicola lacey, The Prisoners' Dilemma: Political Economy and Punishment in Contemporary Democracies 55-67 (2008).

120. Vincent Chiao, Criminal Law in the Age of the Administrative State 35-50 (2019). 
and social resources, or what desistance theories call human and social capital. ${ }^{121}$ Personal resources include "[f]aculties of [b]ody, or [m]ind," "22 such as selfcontrol and good judgment. Social resources include relationships, networks, and institutions that enable individuals to collaborate with other people to pursue, individually or collectively, those things that are good for oneself and for society.

Personal and social resources are not distributed evenly across society. That unequal distribution can create impediments at the personal and group levels to the pursuit of individual and social goods. When it is the government or fellow citizens that create or, through malign neglect, ${ }^{123}$ fail to ameliorate those impediments, the civic bonds of reciprocity and inclusion are strained. Those who are left out and left behind may lose faith that the government promotes their interests. They may reject the dominant rules and expectations of society as failing to ensure that the state lives up to its side of the bargain. ${ }^{124}$ They may regard activities that undermine dominant standards as fair game and as part of resisting or rejecting a state or society that does not treat them as equal citizens.

Desistance argues that citizenship narratives provide reasons for civic engagement and abstention from criminal activity. ${ }^{125}$ It justifies adopting thick, robust, socially productive roles within a civil society. The narratives empower at the individual level, by providing resources and motivations to engage productively with civil society. They empower at the social level by describing the value of the various relationships and networks that embed the individual in a system that values them in return.

Some of the major roles that generate these narratives and facilitate "turning points" out of anti-social behavior and into socially acceptable conduct include family, work, and political engagement. ${ }^{126}$ However, the power to adopt those roles depends upon resources that are unevenly distributed both naturally, by dint of personal capacities, and artificially, through the system of governance adopted by a particular society. A major finding of the desistance movement is that deficits in personal resources - what we might call "human capital" - can be ameliorated through the support of active mentors to motivate individuals to change, and help motivated individuals negotiate the process of social engagement. ${ }^{127}$ Another finding is that the social resources - what we might call "social capital" - can generate integrative opportunities and provide robust feedback loops to keep individuals engaged in socially productive activity. ${ }^{128}$

121. McNeill, Desistance Paradigm, supra note 19, at 50; McNeill et al., Reexamining Evidence-Based Practice, supra note 10, at 47; McNeill, What's Just?, supra note 19, at 24.

122. Thomas Hobbes, Leviathan 62 (First Ave. Editions 2018) (1651).

123. Michael Tonry, Malign Neglect—Race, Crime, and Punishment in America 209 (1995).

124. SHELBY, supra note 12, at 192.

125. MARUNA, MAKING GoOD, supra note 1, at 87-90, 97-100.

126. See Laub \& Sampson, Turning Points, supra note 2, at 301-25.

127. McNeill et al., Reexamining Evidence-Based Practice, supra note 10, at 47-48.

128. Id. at 49; see also Stephen Farrall, Social Capital and Offender Reintegration: Making Probation Desistance Focused, in After Crime And Punishment: Pathways to OfFender 
Where obstacles are created by the state or civil society, individuals may have good reasons for protesting or resisting roles that produce a debased form of citizenship. ${ }^{129}$ There may seem little difference between the socially endorsed roles on offer, and those that are socially disfavored. Worse, requiring people who are victims of state and community oppression to embrace roles that ignore or dismiss that oppression, perpetuates that oppression. ${ }^{130}$ Where the state itself is impermissibly anti-social, inhibiting groups' access to citizenship and civic engagement, then the state, too, must change. ${ }^{131}$

\section{A. Socially Situated Power}

A desistance-informed perspective frames its assessment of problem-solving courts in terms of reintegration and citizenship. ${ }^{132}$ The process of desistance seeks to leverage both individual personal and psychological resources, coupled with social relationships and networks, to transform both the actual and perceived standing of ex-offenders within the community. ${ }^{133}$

Individuals are differently positioned in their ability to access novel social roles and narratives, given both their psychological ability to motivate themselves to change, as well as their connection to social resources that help to place them there. ${ }^{134}$ Desistance theories have emphasized the power of family, employment, voting, and identity to facilitate the process of personal change. ${ }^{135}$ However, the ability to participate in these institutions is deeply raced and gendered, at the very least, ${ }^{136}$ as well as related to problems of disability and unhousedness that prevent individuals from fully participating in contemporary society.

Social resources are unequally distributed throughout society. Any politics of reintegration must account for individual and structural differences in the

REINTEGRATION 57-82 (Shadd Maruna \& Russ Immarigeon eds., 2004).

129. SHELBY, supra note 12, at 192; KELLEY, supra note 13, at 205.

130. SOYER, supra note 117, at 20 ("When the teenagers I interviewed insisted that they can overcome their disadvantage through hard work, or when they told me that they were the only ones to blame for their incarceration, they inadvertently disclosed that they had accepted their current unequal social position as a given.").

131. Reuben Jonathan Miller \& Forrest Stuart, Carceral Citizenship: Race, Rights and Responsibility in the Age of Mass Supervision, 21 TheORETICAL CRIMINOLOGY 532, 536 (2017).

132. See, e.g., Christopher Uggen et al., 'Less than the Average Citizen': Stigma, Role Transition and the Civic Reintegration of Convicted Felons, in AFTER CRIME AND Punishment 258-90, supra note 128; Farrall, supra note 128.

133. See Uggen et al., supra note 132, at 258, 261-62 (emphasizing the importance of social and personal resources that underly the social-psychological process of desistance).

134. See generallyid. at $258-87$.

135. See id. at 258, 261.

136. See, e.g., Weaver \& McNeill, supra note 11, at 46-54 (discussing the ways in which women, people of color, and Muslim people are societally disadvantaged during the desistance process); see also SOYER, supra note 117, at 25. 
power to access these vehicles for personal transformation. ${ }^{137}$ The state's interest in supporting these civil institutions across different communities embodies " $t$ the crucial boundary ... between the majority class and those who are being defined out of the edifice of citizenship." 138

For example, taking on a robust role over time as a husband ${ }^{139}$ or parent ${ }^{140}$ appears to promote social reintegration. However, the existence of a domestic relationship may not be enough by itself; there is evidence that having a girlfriend could lead to increased criminal activity. ${ }^{141}$ Instead, a person must go through the process of embracing a deep commitment to the project of being a husband with all the responsibilities that entails.

[T] he process of role commitment [can be described] as becoming 'hooked' on a role. Once 'hooked,' new identities are fashioned out of new roles. 'Whole bundles' of behavior inconsistent with the claims of the new self are cast aside, and new bundles that are expressive or supportive of that role are picked up. ${ }^{142}$

In turn, the social relationships that marriage generates, including the spouse's and extended family's standing to criticize failures in fulfilling the responsibilities of marriage, provide a structure and set of values through which the person reintegrating into society can hold themselves accountable with a new sense of self, and have their family hold them accountable in this new way too. ${ }^{143}$

Other family connections can provide important new roles for people motivated to move on from criminal activity. For example, family connections may also be related to the ability to find employment, which is another important social role that changes both the way that the individual thinks about themselves, and how society views those individuals. ${ }^{144}$

However, access to family connections, whether as a spouse in a committed relationship or as a parent, spouse, child, or sibling, is not evenly distributed across society. ${ }^{145}$ These uneven distributions "vary by race and social class." 146

137. See McNeill, What's Just?, supra note 19, at 22-23 (discussing the relationship and disparities between inequality and probation services); see generally Yankah, supra note 118, at 74-112 (using a range of political and civic rights to examine reintegration as a state's obligation and an offender's right).

138. LACEY, supra note 119, at 6 (2007) (quoting RALF DAHRENDORF, LAW AND ORDER 98 (The Hamlyn Trust, 37th ed. 1985)).

139. See Laub \& Sampson, Understanding Desistance, supra note 10, at 21.

140. See Shadd Maruna \& Kevin Roy, Amputation or Reconstruction? Notes on the Concept of "Knifing Off" and Desistance from Crime, 23 J. Contemp. CRIM. Just. 104, 116 (2007).

141. Laub \& Sampson, Understanding Desistance, supra note 10, at 21.

142. Uggen et al., supra note 132, at 263 (citation omitted).

143. See generally id. (discussing the range of effects marriage has on an offender's ability to develop a stable and coherent identity within society).

144. See id. at 266-69.

145. See Laub \& Sampson, Understanding Desistance, supra note 10, at 55-56.

146. Id. 
Just as strong family and employment relationships permit socially productive roles, weak relationships can lead to anti-social roles. ${ }^{147}$ Where marriage, family, work, and even friendship are unevenly distributed resources - empowering some individuals or social groups and disempowering others - there exists a cause to worry about the nature of a state that tolerates such differences in status and social integration. ${ }^{148}$

These criminal justice impacts on citizenship and social integration are particularly prominent along the lines of race. In the United States, hypercriminalization

does more than condemn its largely poor and black targets to second class citizenship; criminalisation and penalisation constructs a new kind of 'carceral citizenship', which renders certain subjects suitable for governance through institutions of both control and care. . . . changing their relations with state agencies and civil society associations, drawing them into supervision and empowering other public and private actors to 'manage, correct, sanction and care for them.'149

\section{B. The Uncritical Endorsement of Problem-Solving Courts}

When we turn to problem-solving courts as reintegrative institutions, the question becomes: How effectively do the courts provide individual and social resources for change through the relationships with judges and team members?

The desistance movement exhibits a curious tendency to regard problemsolving courts in general, but reentry courts in particular, as institutions that promote the citizenship and social justice goals of desistance. ${ }^{150}$ Oddly, for a movement so invested in evidence-based and ethnographic studies of what works ${ }^{151}$ the desistance descriptions of problem-solving courts never engage with court practices on the ground. Indeed, they do not readily engage with the critiques of problem-solving courts at the level of doctrine and theory or at the level of critical ethnography.

There are a variety of critiques that should cause desistance theorists to be wary of problem-solving courts. For example, if desistance seeks to promote reintegration into society, then the drop-out rate of problem-solving courts should

147. See id. at 56 (describing the impact of gang-involvement and alcohol on adult social dynamics).

148. See generally Chiara Cordelli, Distributive Justice and the Problem of Friendship, 63 Pol. Stud. 679, 683 (2015) (addressing the inequalities associated with friendships and acknowledging friendship as a "legitimate subject of justice").

149. McNeill, Pervasive Punishment, supra note 87, at 55 (citing Miller \& Stuart, supra note 131 , at 534,536$)$.

150. See Maruna \& LeBel, supra note 20, at 91-107 (analyzing the core elements of reentry courts that are derived from the basic components of problem-solving courts).

151. See, e.g., McNeill, What's Just?, supra note 19, at 31. 
be deeply alarming. ${ }^{152}$ If the goal of desistance is to promote individualized, strengths-based narratives, then the resistance of problem-solving courts toward practices that stray from medicalized or therapeutic understandings of agency ought to be a red flag. If the goal is to emphasize positive narratives to develop socially adaptive identities rather than using incarceration as a shock-inducing ${ }^{153}$ turning point, ${ }^{154}$ then the problem-solving court is troubling. If the goal is to emphasize individualized processes tailored towards motivating particular persons, then the problem-solving court's reliance on generic treatment programming that treats all participants the same is contraindicated. ${ }^{155}$ If the goal is to focus on strengths, not problems, then the problem-solving court is, well, a problem.

There is evidence that Latinx people ${ }^{156}$ and African Americans fare worse in problem-solving courts than other populations. ${ }^{157}$ One reason may be that for many people of color, there is a stigma attached to disability and especially mental disability. ${ }^{158}$ Accordingly, many people of color resist therapeutic explanations for their anti-social conduct. Another reason may be that therapeutic explanations minimize the rational resistance of people of color to a criminal justice system that unfairly targets and stigmatizes them. ${ }^{159}$ The problem-solving

152. See, e.g., Huddleston \& Marlowe, supra note 34, at 33 (discussing graduation rate of 40 $65 \%$ of participants, with an average of $53-57 \%$, which means that the drop-out rate was $60-35 \%$ of participants, with an average of $47-43 \%$ ).

153. Boldt, Rehabilitative Punishment, supra note 49, at 1211.

154. SOYER, supra note 117 , at 70.

155. See Josh Bowers, Contraindicated Drug Courts, 55 UCLA L. REv. 783, 784-88 (2008) (acknowledging the disparities in the application and effectiveness of drug courts).

156. Nolan, JR., Reinventing Justice, supra note 6, at 124 (cultural stigma towards disability treated in problem-solving court as anti-therapeutic).

157. See Randall T. Brown et al., Treatment Retention Among African Americans in the Dane County Drug Treatment Court, 48 J. Offender ReHABILITATIOn 336-49 (2009); Adela Beckerman $\&$ Leonard Fontana, Issues of Race and Gender in Court-Ordered Substance Abuse Treatment, 33 J. OfFENDER REHABILITATION 45-61 (2001).

158. See, e.g., Josh Lukin, Disability and Blackness, in The DisABility Studies ReADER 31112 (Lennard J. Davis ed., 2013).

159. A particularly powerful statement of this view is Dr. Alan Stone's Parable of the Black Sergeant. Alan A. Stone, Presidential Address: Conceptual Ambiguity and Morality in Modern Psychiatry, 137 Aм. J. Psychiatry 887, 887-88 (1980). The sergeant was arrested for stealing government property and was initially diagnosed as a kleptomaniac. Id. However, in discussion with his army psychiatrist, he revealed that: "As the years passed he became increasingly bitter. He was convinced that life had cheated him because he was black and that the Army, in the work and position it gave him, continued to discriminate against him. Out of this sense of being cheated there grew a sense of entitlement, and he came to feel that he was justified in taking whatever he could whenever he could. He had no sense of being impulsively driven to steal Army property; instead, he stole with a sense of entitlement and reparation in protest of the racist world that had deprived him of his hopes." Id. at 888 . Had he maintained his silence, he would not have been prosecuted. $I d$. However, by admitting his act of racial revenge, he was guilty of committing a crime. $I d$. For 
court's focus on personal responsibility rather than social obstacles to reintegration fails to respect and engage with the challenges faced by Black people caught up in the criminal process. ${ }^{160}$ As a consequence, perhaps, African Americans are less likely to endorse the therapeutic narrative as the major source of their problems with the law. ${ }^{161}$ When participants fail to graduate, they are sentenced more harshly than had they never entered the court in the first place. ${ }^{162}$

\section{RAISING UP THE LOWER COURT JUDGE}

Problem-solving courts do operate as a form of institutional political empowerment that transforms social roles, permitting the adoption of a new, strengths-based and identity-changing narrative that enables an increase in status and integration into the community. However, the beneficiary of this new identity is not the person reentering society from prison, but the problem-solving court judge.

Consider the rise of the problem-solving court from the perspective of Malcolm Feeley's famous study of a low-level criminal courthouse in New Haven, Connecticut. ${ }^{163}$ This study presents a depressing account of lower criminal courts. Whilst limited in scope, Feeley's account presents a familiar story of disaffection among the functionaries of the low-level criminal justice system. His account is useful to exemplify the attitude of these court officials towards the criminal justice process and their place within it.

A central feature of the process in low-level criminal courts is the officials' search for respect from their peers and from the public, and that the sense of failure produced by criminal courts is shared by many of the professionals working there. Problem-solving courts respond to this lack of respect by portraying themselves as treatment experts, so that the judges increase their standing among their target audience: their peers and superiors in the criminal justice system. ${ }^{164}$

According to Feeley, traditional judges are "bored by their jobs [and] . . f feel frustrated and belittled." 165 Working with primarily misdemeanants, they are

other versions of this sort of "impure" resistance to unjust laws, see, e.g., SHELBY, supra note 12, at 256-57; KELLEY, supra note 13, at 205.

160. See, e.g., SOYER, supra note 117, at 25 ("The narrative of the 'American Dream' was a meager placeholder for effective rehabilitation. This cultural trope distracted juvenile offenders and juvenile justice employees from the facts of failing infrastructure, limited economic opportunities, and racism.").

161. Beckerman \& Fontana, supra note 157 , at $48-49$.

162. Bowers, supra note 155 , at 792.

163. See FEELEY, supra note 72.

164. Lawrence Baum, Judges and their Audiences: A Perspective on Judicial BEHAVIOR 30 (2006) (“ To achieve their positions, most officials had to work hard to appeal to some combination of higher officials, politicians, and voters. Once in office, they continue to engage in impression management.").

165. FEELEY, supra note 72, at 4. 
treated with contempt by their peers in higher courts. ${ }^{166}$ In this system, everyone experiences burnout. Even the clientele is uninteresting: "nearly all of the defendants are failures, both in life and in crime ... . A great many of them have come to rely on alcohol and drugs . . ."167 Many of the problems are insurmountable by traditional representational methods. Judges, prosecutors, and defenders get irritated at being treated without respect.

Contributing to the dour atmospherics of the lower court, its revolving door model of court processing has serious legitimacy costs. Anthony Thompson suggests that the hyper-criminalization of drug crime during the 1980s and 1990s pushed the sort of low-level drug users that comprise a major part of the lowercourt clientele from the periphery to the center of the legal system, ${ }^{168}$ often in ways that had racial, class, and gender effects. Communities became increasingly worried about the disparate impact of the criminal justice system, including at the front end, in lower criminal courts. ${ }^{169}$

One way to respond to the institutional and social costs of minor crime would be to turn to diversion programs. Historically, however, diversion has failed to ameliorate the reputational and institutional costs borne by the lower-court judges. ${ }^{170}$ Feeley identifies three traditional rationales for and pitfalls with diversion: social benefit, reduction of social control, and efficiency. ${ }^{171}$ The social benefit is providing some substitute for the "harsh formal process of adjudication." 172 The social control benefit is in addressing a core problem of low-level criminality: the system confronts "minor offenses which many do not even regard as 'criminal." "173 Accordingly, diversion's benefit lies in channeling offenders out of the system to avoid over-penalizing minor crimes. ${ }^{174}$ The efficiency benefit is providing more time in court for the more serious crimes. ${ }^{175}$

Feeley suggests three ways in which diversion fails to deliver these benefits. First, the diversion programs he studied are relatively harsh as measured by desired outcome. ${ }^{176}$ "[M] ost of those arrested are not interested in [the program], and prefer to follow the standard path of adjudication." 177 Diversion is "lengthy and cumbersome" as compared to a small fine or immediate dismissal. ${ }^{178}$ Second, "diversion represents a net expansion of social control"179; some $20-30 \%$ of

166. Id. at 4-5.

167. Id. at 4 .

168. Thompson, Courting Disorder, supra note 75, at 68 .

169. Id. at 66-69.

170. FEELEY, supra note 72, at 234.

171. Id.

172. Id.

173. Id.

174. Id.

175. Id.

176. Id.

177. Id.

178. Id.

179. Id. 
offenders who had their cases dismissed "after participation in the diversion program would probably have had their cases [dismissed] outright had they not participated." 180 Furthermore, none of the participants in the process would have received a harsh sentence had they refused to participate. ${ }^{181}$ Third, the process is inefficient, because it detracts from the "informal routines" that permit the court "to handle business rapidly and efficiently." ${ }^{182}$ A feature of low-level criminal courts is the informal, rote nature of much of courtroom procedure. Diversion, to the extent it does not fit into the business-as-usual of the court, disrupts that process.

One way to understand problem-solving courts is as turning these lemons into lemonade: the problems become the benefits. First, the length and harshness of the program become the necessary means of controlling relapse. Second, the net expansion of social control to minor crimes becomes, in the problem-solvingcourt context, a willingness to focus on quality-of-life concerns or an attempt to treat repeat offenders. Third, the disruption of one set of informal routines is replaced by the creation of another set, structured around a therapeutic or restorative justice model of court specialization, promoting innovation and altered roles for the participants in the process.

On this view, problem-solving courts are not a radical departure from a failed history of rehabilitation and diversion, but a reconfiguration of past programs to frame the costs of the cases in terms acceptable to the major audiences such courts address. Those audiences are not limited to the public (though problemsolving courts are interested in persuading the public of their mission). Other audiences for problem-solving courts are the legislature and the prosecutor. The sorts of appeals these addressees find persuasive revolve around recidivism and public safety.

Assigning the reentering person a thick role as in need of expert treatment allows the court personnel to assign themselves a thick role, too. In this case, it is the role of addiction expert, someone who has a special pragmatic expertise that other judges lack. ${ }^{183}$ Accordingly, problem-solving court judges can demand increased respect from their appellate peers as having a greater understanding of conditions at the carceral coalface (as it were), based on something more than anecdote or individual experience. More importantly, empirical data permits the government to choose investment in problem-solving courts as a financially responsible approach to crime in cash-strapped times. And federal support translates into increased respect.

Prosecutors can also endorse problem-solving courts as providing increased surveillance of low-level criminals. Understood as disciplinary institutions, problem-solving courts provide vastly extended contact with low-level criminals in a manner that is relatively costless for prosecutors. After all, it is not the

180. Id.

181. Id.

182. Id.

183. See Richard C. Boldt, Problem-Solving Courts and Pragmatism, 73 MD. L. REv. 1120-72 (2014). 
prosecutor, but the court and the treatment provider that are running the program. Jessica Eaglin has called this process "neorehabilitation":

Unlike the old rehabilitative model, neorehabilitation does not merely seek to improve the offender, but to manage the risk of recidivism through responsibilization and the use of particular tools to improve treatment and reduce the likelihood of future crime. Neorehabilitation thus identifies and manages offenders through treatment for the benefit of society, not the individual. ${ }^{184}$

Neorehabilitation leverages the court's expertise in risk assessment and addiction in ways that increase and deepen the participant's contacts with the criminal process, rather than reduce them. Problem-solving courts' emphasis on recidivism turns judges into the people most closely identified with the costs and benefits of diversion. It permits the judges to resolve some of the difficulties that come with wielding the power to sentence in a regime of mass incarceration. Rather than sending everyone to prison, the judge can feel good about saving participants from the cycle of recidivism. Unfortunately, it is not clear that this narrative is true. ${ }^{185}$

However, the problem-solving-court model also presents a cautionary tale for desistence proponents. To the extent that desistance measures success by integration or "assimilation" 186 into the dominant society, desistance is likely to reflect the norms and mores of that society, for good and ill. However, for many people in the United States, their status as "criminal" is inherently bound up with their status as homeless, or disabled, or their identity as transgender, or Muslim, or Mexican, or Black. Furthermore, for members of these groups, their ability to avoid recriminalization, and so to shed their anti-social identity effectively, is in part in the hands of the police themselves who retain the discretion to direct their investigatory attention more or less intensely towards certain communities or social groups.

On this view, a criminal identity may be both unavoidable and a matter of civic resistance for some groups. These groups may find the very bonding and bridging social capital that knits them tightly into social support groups from groups that the dominant society rejects and the police regard as suspect. This possibility is all the more likely when the police (and even the prosecutor and the court) themselves adopt and enforce racial, ethnic, sectarian, and sexualorientation-based biases, and these biases are well known to the subjects of policing, and resisting these biases (and so the officials, the society, and even the state that perpetuates these biases) becomes a matter of self-respect.

For desistance theorists, then, the inherently political nature of social identity in societies structured by racial, gender, property, and religious hierarchies must

184. Eaglin, supra note 93, at 201.

185. See David Rauma, Fed. Judicial Ctr., Evaluation of a Federal Reentry Program Model (2016) (suggesting that federal reentry court is no more effective than supervision by a probation officer).

186. See McGuInN, supra note 115 , at 12. 
form a central part of their theory and practice. "For too many men and women in prison, structural disadvantage has disempowered, manipulated, and owned them and their communities. Desistance needs to be about returning power, ownership, control." ${ }^{187}$ In Michaela Soyer's study of Boston and Chicago youth involved in the criminal justice system, she contrasted Maruna's description of desistance organized around an optimistic and strengths-based narrative organized around the "American Dream," with:

The myth of American meritocracy obscured racial discrimination and cumulative disadvantage. Unaware of the historical and structural forces that contributed to their marginalization, the teenagers took a highly individualistic approach to explaining their recidivism. They blamed themselves for making "bad choices," for not "listening" to the adults in their lives, or for being "stupid." Their imagined desistance was outcome-oriented and contained unrealistic expectations of radical change. ${ }^{188}$

The problem with both problem-solving courts and desistance movements focused on secondary or individual desistance is that they bump up against a world that resists respecting the majority of individuals who are involved in the criminal justice system. That disrespect does not begin once individuals are labeled criminal or deviant: instead, it predates - but anticipates - contact with the criminal justice system, and persists once these socially marginalized individuals are returned to the community. The social statuses and beliefs that go along with being Black, indigent, houseless, transgender, disabled, immigrant, Muslim, and so on, in the United States (and elsewhere) are part and parcel of the process of criminalization, not separate from it. ${ }^{189}$

Desistance must therefore negotiate both impure integration into certain socially adaptive identities whilst retaining the possibility of impure resistance to a discriminatory and unjust criminal process and society at large. ${ }^{190}$ Perhaps a central aim of the (strengths-oriented) desistance movement- to convert disempowered patients into empowered agents - is capable of achieving this feat in combination with other engaged social change agents. Nonetheless, given the decades-long resistance to social transformation in the United States (at least),

187. Id. at 46 .

188. SOYER, supra note 117 , at 133.

189. Soyer describes juvenile confinement, at least for first-time offenders, as being (ironically, perhaps) a place that allowed juveniles in Boston and California to imagine that they could desist by an act of personal commitment (Id. at 60-61) - much like the problem-solving court's emphasis on responsibilization. Eric J. Miller, Drugs, Courts, and the New Penology, supra note 46, at 443. However, upon release, these youth found it almost impossible to scale, on their own, the various obstacles society had placed in their way. SOYER, supra note 117, at 60-61. Desistance theorists can take some solace in the idea that a dedicated caseworker could provide some meaningful help. Id.

190. I use the terms "impure integration" and "impure resistance" by analogy with Tommie Shelby's concept of “impure dissent." See SHELBY, supra note 12, at 256-58. 
both the problem-solving courts and desistance theorists focused on a narrative of personal transformation must acknowledge:

[the] subtle forms of marginalization that operate through narrative and governmental resource allocation. ... If we want to improve the situation of young minority men, we need to accept their right to live fulfilled and meaningful lives just as middle-class children do. ${ }^{191}$

\section{CONCLUSION}

The process of desistance promises to promote integration and citizenship status for people stigmatized by the criminal justice system. That process depends, in part, on skilled professionals engaged with vulnerable people reentering society. That society may be organized in ways that present severe obstacles to poor Black people who are the most severely criminalized.

A core difference between the desistance process and the problem-solving court process is the way in which desistance theories attempt to account for these social injustices. Rather than hide behind a rhetoric of treatment, desistance recognizes the disparate access to social goods experienced by offenders and can incorporate that as part of the process of integration.

Problem-solving courts, though they share some of the superficial features of the desistance process, are not desistance courts. Desistance theorists should engage more critically with the problem-solving model if they want to be true to the goals of promoting citizenship, social justice, and reintegration that lie at the heart of much of desistance theory.

191. SOYER, supra note 117 , at 136. 